\title{
The Art of Laughing: A Study of the Tempo-Spatial Matrix in Oliver Goldsmith's She Stoops to Conquer
}

\begin{abstract}
Oliver Goldsmith's She Stoops to Conquer (1773) was staged only two weeks after the publication of his Essay on the Theatre, in which he famously compared sentimental comedies with what he described as laughing comedies. The play thus illustrates Goldsmith's principles for his ideal laughing comedy. One of the aspects of this type of comedy, which has rarely been addressed, is its representation of the matrix of temporal and spatial elements, or what Mikhail Bakhtin calls a chronotope. The present study is thus aimed at investigating She Stoops to Conquer in terms of Bakhtinian chronotope. The study argues how different chronotopes have influenced the behaviours as well as the decisions of characters in the play. Moreover, it shows that the chronotopic framework can shed new light on the play's portrayal of the class divisions in the eighteenth century, when the middle class was emerging in England's social system.
\end{abstract}

Keywords: chronotope, Mikhail Bakhtin, Oliver Goldsmith, sentimental comedy, laughing comedy

\section{Umetnost smeha: Študija časovno-prostorske matrice v komediji She Stoops to Conquer Oliverja Goldsmitha}

\section{POVZETEK}

Komedija She Stoops to Conquer (1773) Oliverja Goldsmitha je bila uprizorjena le dva tedna po izidu njegovega vplivnega razmisleka o gledališču "Essay on the Theatre«, v katerem je primerjal sentimentalne komedije s tem, kar je imenoval komedije smeha. Igra torej udejanja Goldsmithova načela za idealno komedijo smeha. Eden od vidikov tovrstne komedije, o katerem do zdaj ni bilo veliko govora, je značilna reprezentacija časovnih in prostorskih elementov oziroma tega, kar Mihail Bahtin imenuje kronotop. Pričujoča študija analizira She Stoops to Conquer z vidika bahtinovskega kronotopa, njen namen pa je pokazati, kako različni kronotopi vplivajo na vedenje in odločitve likov v tej komediji. Članek tudi ugotavlja, da lahko upoštevanje kronotopskega okvirja pomembno prispeva k razumevanju predstavljenih razrednih razlik v 18. stoletju, ko se je v angleškem družbenem sistemu začel oblikovati srednji razred.

Ključne besede: kronotop, Mihail Bahtin, Oliver Goldsmith, sentimentalna komedija, komedija smeha 


\section{Introduction}

Very few - if any - literary critics would bother to regard the eighteenth century in terms of its dramatic productions. And while it is true that the age did not produce many remarkable plays - especially when compared to the previous century, dubbed 'the golden age of English drama' - it was a time when a few exceptional playwrights contributed to, sometimes significantly, the development of drama in Britain.

None of these exceptional dramatists was "at once so loved and so misunderstood" (Bredvold 1966, 137) as Oliver Goldsmith (1728-1774). The versatile Irish author produced a diverse range of literary works that mostly addressed social issues of the day. While it was not difficult for Goldsmith to gain the support of the public, as well as influential contemporary authors such as Samuel Johnson and Thomas Gray, in his lifetime, his reputation has been on the decline since his death.

Goldsmith's drama is now chiefly remembered as a reaction to the then prevalent and popular sentimental comedy. However, with regard to She Stoops to Conquer (1773) - the play which was performed in London two weeks after the publication of Goldsmith's brief but famous Essay on the Theatre, or, A Comparison between Laughing and Sentimental Comedy (1773) - very few studies have endeavoured to analyse the play's matrix of temporal and spatial elements, or what Mikhail Bakhtin describes as a chronotope. ${ }^{1}$

Bakhtin expressed his idea of the chronotope as part of his theory of dialogism. In his essay "Forms of Time and of the Chronotope in the Novel", Bakhtin defines a chronotope as the "intrinsic connectedness of temporal and spatial relationships that are artistically expressed in literature" $(1981,84)$. He states that in literary chronotopes,

spatial and temporal indicators are fused into one carefully thought-out, concrete whole. Time, as it were, thickens, takes on flesh, becomes artistically visible; likewise, space becomes charged and responsive to the movements of time, plot and history. This intersection of axes and fusion of indicators characterizes the artistic chronotope. $(1981,84)$

Very much under the influence of Kant, Bakhtin believes that a subject can only experience the world through time and space; that is, time and space are for Bakhtin epistemological entities. In other words, according to Bakhtin, chronotopes are constitutive elements of the fictional worlds in which the subjects exist. Each subject constructs their worldview according to their surrounding chronotopes. Thus, such 'chronotopic seeing' only occurs in relation to human actions, without which the chronotopes would lose all their meanings and

James Evans (2015) has studied the intertexual links between Goldsmith's play, George Farquhar's The Beaux'Stratagem (1707) and William Shakespeare's A Midsummer Night's Dream (1595). Evans notes that Goldsmith's working on the concept of space is unique because the play's "setting adds resonance to his comic representation of status and gender" $(2015,35)$. In another remarkable study, Christopher K. Brooks (1992) has stated that the play entails a unique space that enables lovers to interact independently of their social classes. The only other notable instance in this regard is Marshall Brown's study of Kantian time and space before the advent of romanticism. Brown argues that Goldsmith's approach toward time and space in She Stoops to Conquer serves to "define but not yet quite to perfect what romanticism was to know as organic form" $(1991,9)$. 
effects. Keith Harrison opines that "Bakhtin's concept of the chronotope allows for a concrete understanding of the significant temporal-spatial design choices that authors make that enable narration and dramatization" $(2017,31)$. As She Stoops to Conquer was Goldsmith's dramatic attempt to offer the English stage an alternative to sentimental comedies, the research will investigate how Bakhtin's chronotope can be used as an analytical tool to revisit the play, and demonstrate how the Irish playwright achieved his purpose.

\section{Goldsmith's Characters and Chronotopic Behaviours}

In his discussion of the physical instances of chronotope, Bakhtin contends that castles, provincial towns, roads, thresholds, inns, etc. have long been the locus of action in a literary work. Any change in these chronotopes in a single work leads to important alterations which, in turn, create crucial moments in the course of events and fate of characters. The plot of She Stoops to Conquer is basically made up of comic incidents that ensue from mistaking the chronotope of an inn for that of a mansion. This not only affects the course of events but creates significant changes in the behaviours of the two guests, Marlow and Hastings, who inadvertently treat the owner of the mansion, Mr. Hardcastle, as an innkeeper. The chronotopic framework of the play is nevertheless set even before the arrival of Marlow and Hastings. From the very beginning of the play, Goldsmith portrays Mr. Hardcastle and his wife as representatives of two opposing chronotopes. While Mr. Hardcastle is fond of the country chronotope and "every thing that's old: old friends, old times, old manners, old books, old wine," Mrs. Hardcastle despises "such old-fashioned trumpery" ([1773] 1998, 96), as it deprives her of living in her beloved town chronotope. Mrs. Hardcastle thinks her engagement with the town is enough to make her superior to her neighbours:

We Country persons can have no manner at all. I'm in love with the town, and that serves to raise me above some of our neighbouring rustics; but who can have a manner, that has never seen the Pantheon, the Grotto Gardens, the Borough, and such places where the Nobility chiefly resort? ([1773] 1998, 116)

But for Mr. Hardcastle, his wife's ideal chronotope is nothing but a time-place element that "cannot keep its own fools at home" ([1773] 1998, 96).

The clash between past and present chrono-makers as well as the conflict between rural environment and urban area topo-makers can be interpreted as Goldsmith's concern over the social impact of the rapid process of urbanization in eighteenth-century England. Peter Borsay argues that "in the eighteenth century the British Isles became the most dynamic area of urban development in Europe, and - perhaps - in the world" (2002, 196). John Rule carried out a comprehensive study of the growth of urban population in England throughout the century, and maintains that

in 1700 it has been estimated that 13.4 per cent of the population lived in towns of 10,000 or more inhabitants. By 1800, 24 per cent did so, and this compared with just 10 per cent for north and west Europe minus England. $(2002,128)$

Similar studies have also shed light on the increase in the proportion of the urban population over the eighteenth century across England. Goldsmith's country-versus-city chronotopic 
struggle is thus the dramatist's comic illustration of the deepening chasm between two ways of living as well as two modes of thinking; a concern he frequently touched upon during his career as an author and critic, especially in his 1770 poem The Deserted Village.

Town and countryside are not the only conflicting chronotopes of the play. Tony Lumpkin, Mrs. Hardcastle's son from her previous marriage, has his own desirable chronotope, which is strongly denounced by his mother and stepfather. He likes hanging out at the ale-house and enjoying the present moment. Tony's chronotope, thus, is in sharp contrast with that of his stepfather, both in terms of temporal and spatial elements. In the words of his stepfather, Tony does not deserve to live in the mansion chronotope and must be relegated to "the ale-house and the stable" ([1773] 1998, 97). Tony himself prefers the ale-house chronotope as it allows him not only to defy his parents' restrictions, but to make fun of all the rules and regulations imposed by social and religious institutions, such as school and church. Interestingly, Tony is spending time in his favourite chronotope when he comes up with his decisive joke and deceives Hastings and Marlow into believing that Hardcastle's mansion is an inn.

The inclination of Goldsmith's characters toward a particular chronotope has influenced not only their personalities but their decisions and behaviours. Mrs. Hardcastle's longing for London has made her an avid fan of "the Scandalous Magazine" and "Ladies Memorandumbook" ([1773] 1998, 116). Mr. Hardcastle's love for everything that is old is reflected in his interest in telling old stories. In fact, he is offended by Marlow's behaviour chiefly because he dares to interrupt one of his best stories: "When I was in my best story of the Duke of Marlborough and Prince Eugene, he asked if I had not a good hand at making punch" ([1773] 1998, 120). Mr. Hardcastle's main source of frustration is, in other words, his guest's irreverent attitude to his most cherished chronotope.

The impact of chronotopes on the behaviours of characters in She Stoops to Conquer is perhaps best manifested in Marlow's dialogues with Mr. Hardcastle and Kate before and after he realizes his mistake. When deceived by Tony, Marlow mistakes Hardcastle's mansion for an inn. He describes Mr. Hardcastle as "a very impudent fellow" ([1773] 1998, 111) and "a very troublesome fellow" ([1773] 1998, 109) whom he ventures to make fun of. Marlow's unexpected behaviour irks Mr. Hardcastle, who can't put up with "such a brazen dog" ([1773] 1998, 110) and decides to throw him out of his house. For Mr. Hardcastle, Marlow's "modern modesty" resembles "old-fashioned impudence" ([1773] 1998, 111); a comparison which once again confirms the influence of chronotope on the characters of the play. The change in Marlow's behaviour is also clear in his conversations with Kate. While Marlow keeps addressing Kate as 'madam' when he talks to her as Hardcastle's daughter, he uses words such as "child", "dear me" ([1773] 1998, 132), and "my pretty simplicity" ([1773] 1998, 133) when he chats with her as a barmaid. Once Marlow realizes his mistake - which we might call a chronotopic mistake - he is so disturbed that he thinks "there's no bearing this; it's worse than death" ([1773] 1998, 146). He is, in fact, struck by the incongruity of his behaviour at the Hardcastles'. Bakhtin contended that "the image of man is always intrinsically chronotopic" $(1981,85)$. Marlow's image was contaminated because his behaviour didn't match the conduct that was expected from him when he was situated in the tempo-spatial matrix of the mansion. 


\section{Chronotope and Eighteenth-Century Social Classes}

Although Marlow's behaviour toward Mr. Hardcastle is a reflection of the chronotopic influence on the characters' demeanours in Goldsmith's comedy, his interactions with Kate reveal that a chronotope can even form one's perception of the social class system. Goldsmith's play was produced in the context of the eighteenth-century ferment over social classes. Nicolas Hudson notes that due to "the advent of industrialism and later the panic sown by the French Revolution" in this era, "we can speak adequately of an English 'class' system" (2003, 11). It was also the time when "modern theories of identity - particularly class, gender, and sexuality came into being" (Straub 2009, 5). While Britain was facing the emergence of the middle class for the first time, the interactions among different classes of the society remained a disputable topic. P. J. Corfield contends that "an endless debate about the number and nature of social classes began in the 18th century" $(1987,39)$. So strong was the debate over social classes that it even invoked numerous variations of the Great Chain of Being: "A well-ordered sequence of ranks and degrees in human society was part of a divinely-ordained hierarchy that embraced the whole of creation" $(1987,40)$. The middle class, in particular, was not a coherent division of the society. Paul Langford argues that there wasn't

necessarily much resemblance between the middling countryman, a substantial tenant farmer soon to be dignified perhaps by the title of gentleman farmer, and his urban counterparts, the businessman, doctor, and lawyer, who throve on early industrial society. $(2000,55-56)$

Goldsmith's representation of country and city chronotopes is a reflection of the growing split within this "diverse and highly differentiated group" (Berg 2005, 195), one known as the middle class.

Within this context, it is not surprising that Goldsmith addressed this new field of inquiry, i.e. social classes, in She Stoops to Conquer. While Goldsmith shows no interest in making or even inspiring changes in the British social class system, his concern over the status of the newlyformed middle class is explored in the play. ${ }^{2}$ Kate and Marlow emerge from the same social class. However, as the bashful guest is uncomfortable in the company of women of his own class, Kate stoops to the working class and pretends to be a maid in order to conquer him. Kate's plan is, in fact, stooping from the chronotope of the mansion to that of the inn. Although Kate's act of degradation defies the rules of her class, she does it only temporarily in order to prove to Marlow that he is indeed able to connect with a woman of his own middle class.

Kate's scheme works as Marlow's behaviour completely changes when he finds himself in the company of a maid and not Hardcastle's daughter. In other words, the chronotope that Marlow associates Kate with determines her class. And this social class, in turn, directs his

Some critics, including Robert W. Seitz, argue that Goldsmith admired the English middle class due to his Irish experiences. Seitz states that "this veneration was prepared for by the relative non-existence of such a class in Ireland. Upon his arrival in England he became acutely aware that he was the victim of this defect in his early environment" $(1937,405)$. Seitz also opines that "the English middle class of which Goldsmith became the self-appointed champion are, at least in their preoccupation with festival celebrations, curiously reminiscent of the country-folk he had known in his youth" $(1937,405)$. 
attitude and behaviour, and shapes his two different characters. Kate draws attention to Marlow's opposing behaviours when she asks:

In which of your characters, Sir, will you give us leave to address you. As the faltering gentleman, with looks on the ground, that speaks just to be heard, and hates hypocrisy; or the loud confident creature, that keeps it up with Mrs. Mantrap, and old Miss Biddy Buckskin, till three in the morning; ha, ha, ha. ([1773] 1998, 146).

Here, Goldsmith is inviting his audience to notice a distinction between two families or "social classifications" (Flint 1995, 137) of the eighteenth-century middle class, separated by their domineering chronotopes.

The character of Marlow makes it clear that a chronotopic change can alter the conduct of a person tremendously, even if their social class remains the same. Marlow's reserve can also be investigated in light of the chronotope that has surrounded him for most of his life: London. The process of urbanization and the rise of the middle class created new standards for social conduct in populated cities across England. At the centre of such standards was urban politeness, as promoted by periodicals, including those produced by Addison and Steele, as an indispensable element of interpersonal communication. Catharina Löffler maintains that London as a place where people lived

to see others and to be seen by others demanded proper conduct to prevent social interactions from failing on the one hand and to prevent one's own inappropriate or even embarrassing behaviour and, consequently, bad reputation on the other. $(2017,83)$

The results of Löffler's research again indicate that chronotopes can form and direct the behaviours of human subjects in certain ways. The urban middle-class section of society allows for certain conduct and excludes others. In other words, the chronotope is not limited to a background for Marlow's behaviours and deeds; rather, it comes to the foreground and becomes part of his character and a driving force behind his actions. Marlow "is possessed of more than a competence already, and can want nothing but a good and virtuous girl to share his happiness and encrease it," but his fortune can't give him enough courage and self-esteem to establish a relationship with a girl of his own class whose "fortune is but small" ([1773] 1998, 138). In other words, Marlow's behaviour toward Kate, as Mr. Hardcastle's daughter, is much more influenced by the chronotope of the city than his financial superiority.

We also need to take into consideration the fact that Kate's shift of social class could imply that shreds of the old social order still, consciously or unconsciously, remained in the society as well as the literary world. This social order, which was disturbed by the emergent middle class of the time, could define categories only in terms of aristocrats and peasants. Thus, as Marlow was not yet accustomed to the new social order, he was unable to strike a chord with a middle-class woman like Kate. As a result, Kate had no choice but to drop down a class in order to entice Marlow. This could be seen as an indication that Goldsmith and English society as a whole were not yet adapted to the new social order and, as a result, the emergence of a new class created confusion in at least some social contexts, such as courtship. 


\section{Chronotope and the Ethically Acting Subject}

One of the significant aspects of Bakhtin's concept of the chronotope is its relevance to the category of ethics. The tempo-spatial perspective is concerned with

the evolution of a certain mode of representation where the individual consciousness is involved in a living engagement with the historical environment. The 'chronotope' is a concept borrowed from biology and refers to when an individual organism coevolves with its environment. (McCaw 2016, 7)

In this regard, Liisa Steinby defines chronotope as 'chairlogical', meaning that a chronotope is "time and place not in the physical sense but in the sense of the (right) moment for certain kinds of human action" $(2013,116)$. In other words, certain chronotopes entail certain human actions specific to them. By the same token, they also inhibit the possibilities of human actions. If a certain chronotope calls for a certain experience or decision for a character, it also rules out other experiences as well. Therefore, the decisions taken by human subjects, their experiences, and their characteristics are very much under the influence of their surrounding time and space.

But this implies that human subjects do not possess free will, and that whatever they do is being orchestrated by the external forces in the world. Bakhtin, however, disagrees. It is true that chronotopes affect people's decisions and conditions, but they are not powerful enough to completely deprive human beings of their capacity for free decision-making. Steinby elaborated that "the idea of chronotopic determination of the possible time-space of action in no way diminishes for Bakhtin the characters' responsibility for their acts" (2013, 121). In his Problems of Dostoevsky's Poetics, Bakhtin also studied how the aesthetic form arises from characters that - though conditioned by the locality - are left with the freedom of an ethical choice. Bakhtin tells readers that Dostoevsky's fiction is marked by his insistence on the personality "because of its extraordinary internal freedom and its utter independence from the external environment" (1984, 11-12). Therefore, although characters might be conditioned by the chronotopes, they are nevertheless ethically responsible for their actions.

As discussed earlier, Goldsmith's She Stoops to Conquer makes great use of various chronotopes. While contributing to the comic aspect of the play, these also raise important questions about the morality of characters. The peculiar and mistaken perception of reality leads to particular behaviours and decisions from characters. But are these decisions dictated by the chronotope, or are the characters capable of acting based on their will when situated in such tempo-spatial perspectives?

In her study of social problems in eighteenth-century Britain, Joanna Innes investigates the revival of interest in the reformation of manners movement in later decades of the century. Innes argues that "concern about the corrupt state of contemporary morals formed a persistent theme in English thought, engaging the attention of people at many different social levels throughout the eighteenth century" $(2009,180)$. This interest and concern over the revival of morals in society also affected the agenda of literary circles and communities. In the following paragraphs, we discuss how Goldsmith addressed the issue of making moral decisions in She Stoops to Conquer in the light of prevailing chronotopes of the play. 
In the course of the play, Marlow is faced with various moral dilemmas. In Act IV, he is awarded the chance to be alone with Kate in a room, but he mistakenly thinks it is just an empty room of an inn and Miss Hardcastle an inn barmaid. Although he is not good at conversing with women of the upper class, Marlow has had a rather fine history with women of the working class. This is evidenced by his boasting to his friend Hastings. Therefore, when he is afforded the opportunity of being alone with a barmaid, the idea of making sexual advances fills up his mind. Marlow doesn't see any shame in this decision. When Hastings scolds him about robbing the girl's honour, Marlow simply answers that "we all know the honor of the bar-maid of an inn. I don't intend to rob her, take my word for it, there's nothing in this house, I shan't honestly pay for" ([1773] 1998, 129). His mindset is directed by the fact they are at an inn, or so he believes. In other words, it is the chronotope that prompts this line of thought. This is where Marlow is presented with a moral decision. What he chooses in this dilemma is the high, ethical road, which is made all the more impressive since the surrounding chronotope - an inn - makes it acceptable for him to steal the maid's honour. Reminded by Hastings about the girl's virtue, Marlow replies that "if she has, I should be the last man in the world that would attempt to corrupt it" ([1773] 1998, 129). Although in their first encounter Marlow acts freely and makes a few attempts to kiss Kate, he confesses later on that he is seeking "an honourable connexion" ([1773] 1998, 133), which is impossible due to their differences in rank and position. He elaborates on his intentions, stating that "I can never harbor a thought of seducing simplicity that trusted in my honour, or bringing ruin upon one, whose only fault was being too lovely" ([1773] 1998, 133). Therefore, although Marlow thinks Kate is a barmaid, and the inn chronotope urges him to make a move on her, he refuses to act unethically.

The same pattern of moral dilemma in the face of a chronotope could be seen with regard to Hastings. Unlike Marlow, he finds out early on that he is actually at Mr. Hardcastle's mansion, and not at an inn. However, he uses this information to serve his own interests and refuses to reveal the truth to Marlow. Where Marlow acts morally in his ignorance, Hastings acts immorally in his enlightenment, surrendering to what the chronotope dictates. Marlow himself acknowledges that Hastings left him in his ignorance to be "rendered contemptible, driven into ill manners, despised, insulted, laugh'd at" ([1773] 1998, 136). Although Hastings is in the same predicament as Marlow, he selfishly decides against informing his friend of his mistake, for this trickery would serve his own purpose:

In the meantime, my friend Marlow must not be let into his mistake. I know the strange reserve of his temper is such, that if abruptly informed of it, he would instantly quit the house before our plan was ripe for execution. ([1773] 1998, 112)

His concern with 'our plan' drives away any thought about how things would turn out for his friend Marlow; a behaviour issued and influenced by his recognition of the chronotope.

It is in the character of Tony Lumpkin that Goldsmith's desire for reviving social ethics is mostly displayed. Like Marlow and Hastings, Tony grapples with ethical doubts. $\mathrm{He}$ is perhaps the most intriguing character in the entire play, setting up the confusion that results in the odd conduct of Marlow and Hastings in Hardcastle's mansion, playing a bit-part villain in the early stages of the play and, at the end, turning unexpectedly to save 
Hastings and Miss Neville. From the very first act of the play, it becomes evident that Tony is a spoiled child who has no regard for academic life and spends most of his time at inns and ale-houses in company of people of low rank. He even shuns his intended, Miss Neville, and has his eyes set on a country girl. When we do see him in Mr. Hardcastle's mansion, he's only doing one of the two things: either trying to get back to the inn again, or trying to play a trick to further his self-interest. Thus, it makes sense for him to help out Hastings with his courtship of Miss Neville, because that means he won't have to marry her. Things, however, take a turn at the end of Act IV when Hastings and Miss Neville's plot is discovered, and Miss Neville is forced to leave Mr. Hardcastle's mansion to live in Aunt Pedigree's house. Although it was Tony himself who inadvertently ruined their plans, he offers to help her flee the mansion:

Meet me two hours hence at the bottom of the garden; and if you don't find Tony Lumpkin a more good-natur'd fellow than you thought for, I'll give you leave to take my best horse, and Bett Bouncer into the bargain. ([1773] 1998, 138).

Exhibiting ethical behaviour in the face of external forces, Tony doesn't give in to chronotopic dictations of the locale. His immersion in the ale-house chronotope would urge him to act only in his own interests and disregard others. However, he rejects these forces and decides to do a selfless deed instead.

Marlow, Hastings, Tony, and to a lesser degree, the remaining characters in She Stoops to Conquer, all face moral dilemmas. Regardless of their decisions to choose the ethical path or not, Goldsmith's characters exhibit the possibilities of human individuals to act on their own when they are subject to a dominant tempo-spatial matrix. They exhibit the possibility of the existence of free will and conscious decision-making even in the presence of a dominant chronotope.

\section{Conclusion}

In She Stoops to Conquer, Oliver Goldsmith dramatizes the principles that he considered essential for a laughing comedy, a type of play which he thought was the remedy for the English stage after years of suffering from sentimental drama. Within its chronotopic framework, this research argued that She Stoops to Conquer makes extensive use of tempo-spatial perspectives which serve to fulfil multiple purposes. As "chronotopes are mutually inclusive, they co-exist, they may be interwoven with, replace or oppose one another, contradict one another or find themselves in ever more complex interrelationships" (Bakhtin 1981, 252), the current study showed that the complex interrelationships of chronotopes in the play assisted Oliver Goldsmith in establishing a dialogic network in which contending voices find room to confirm or challenge each other.

The simultaneous use of different chronotopes in the play first of all serves to explain the different and sometimes opposing attitudes and behaviours of the characters. The tension between city, village, inn, and ale-house chronotopes ${ }^{3}$ creates comic moments in the play.

Jordan-Haladyn describes this tension as the interaction of various chronotopes "dialoguing with each other" $(2014,25)$. 
It also helps the playwright to establish a dialogic network among his characters. Thanks to the interrelated chronotopes, Goldsmith's characters display distinctive behaviours, but they are able to make a coherent and dialogic whole that can be called a laughing comedy. This is in line with the conclusion of Daphna Erdinast-Vulcan's study of Bakhtin's philosophical contributions to literature, where she noted that

a text may be constituted by more than a single chronotope, and it is often the relation of the conflicting modes of perception and the tension between them in a single text that render it valuable for the study of culture, since these interactions cross the lines of demarcation between authors, characters, performers, listeners, and readers. $(2013,119-20)$

This study also demonstrated that the eighteenth-century debate over the interactions among the newly-defined social classes, as represented in She Stoops to Conquer, could be investigated as part of the chronotopic matrix of the play. As this paper argued, this is more palpable in the study of the relevance of the emergent middle class to its surrounding chronotopes. As the central course of measure in the play, Kate's act of 'stooping to conquer' Marlow involves several chronotopic transformations which help Goldsmith shed light on the unique features of each class (or subclass) when it comes to differentiating between the middle class members in big cities and those in rural areas in eighteenth-century England.

Finally, the study concludes that Bakhtin's chronotopic matrix can provide the conditions for the co-existence and co-development of the individual's free will and the external temporal and spatial forces which seek to direct human subjects to make decisions or take actions in a particular way. Our research findings suggest that Bakhtin's idea of chronotope can be a novel and useful tool for studies that intend to delve into the mechanisms of the late eighteenthcentury and early nineteenth-century comedies; plays that urge their audience to laugh and not to "sit at a play as gloomy as at the tabernacle" (Goldsmith 1773, 402).

\section{References}

Bakhtin, Mikhail. 1981. The Dialogic Imagination: Four Essays by M. M. Bakhtin. Translated by Michael Holquist and Caryl Emerson. Texas: University of Texas Press.

—. 1984. Problems of Dostoevsky's Poetics. Translated by Caryl Emerson. Minnesota: University of Minnesota Press.

Berg, Maxine. 2005. Luxury and Pleasure in Eighteenth-Century Britain. New York: Oxford University Press.

Borsay, Peter. 2002. “Urban Life and Culture.” In A Companion to Eighteenth-century Britain, edited by H.

T. Dickinson, 196-209. Oxford: Blackwell Publishers.

Bredvold, Louis I. 1966. The Literature of the Restoration and the Eighteenth Century 1660 - 1798. New York: Collier Books.

Brown, Marshall. 1991. Preromanticism. Palo Alto: Stanford University Press.

Brooks, Christopher K. 1992. "Goldsmith's Feminist Drama: She Stoops to Conquer, Silence and Language." Papers on Language and Literature 28 (1): 38-51.

Corfield, P. J. 1987. “Class by Name and Number in Eighteenth-Century Britain.” History 72 (234): $38-61$.

Erdinast-Vulcan, Daphna. 2013. Between Philosophy and Literature: Bakhtin and the Question of the Subject. California: Stanford University Press. 
Evans, James. 2015. "Adapting the Stratagem: Goldsmith's She Stoops to Conquer." ANQ: A Quarterly Journal of Short Articles, Notes, and Reviews 28 (1): 34-38. https://doi.org/10.1080/0895769X.2015 .1036829.

Flint, Christopher. 1995. “The Family Piece': Oliver Goldsmith and the Politics of the Everyday in Eighteenth-Century Domestic Portraiture.” Eighteenth-Century Studies 29 (2): 127-52.

Goldsmith, Oliver. 1773. "An Essay on the Theatre; or, a Comparison Between Laughing and Sentimental Comedy.” Westminster Magazine January: 398-402.

—. (1773) 1998. "She Stoops to Conquer." In Four Georgian and Pre-Revolutionary Plays, edited by David Thomas, 93-151. London: Macmillan Press.

Harrison, Keith. 2017. Shakespeare, Bakhtin, and Film: A Dialogic Lens. Cham: Palgrave Macmillan.

Hudson, Nicholas. 2003. Samuel Johnson and the Making of modern England. Cambridge: Cambridge University Press.

Innes, Joanna. 2009. Inferior Politics: Social Problems and Social Policies in Eighteenth-Century Britain. New York: Oxford University Press.

Jordan-Haladyn, Miriam. 2014. Dialogic Materialism: Bakhtin, Embodiment, and Moving Image Art. New York: Peter Lang Publishing.

Langford, Paul. 2000. Eighteenth-Century Britain: A Very Short Introduction. New York: Oxford University Press.

Löffler, Catharina. 2017. Walking in the City: Urban Experience and Literary Psychogeography in EighteenthCentury London. Wiesbaden: J.B. Metzler.

McCaw, Dick. 2016. Bakhtin and Theatre Dialogues with Stanislavsky, Meyerhold and Grotowski. New York: Routledge.

Rule, John. 2002. “The Labouring Poor.” In A Companion to Eighteenth-century Britain, edited by H. T. Dickinson, 196-209. Oxford: Blackwell Publishers.

Seitz, Robert W. 1937. "The Irish Background of Goldsmith's Social and Political Thought." PMLA 52 (2): 405-411. https://doi.org/10.2307/458598.

Steinby, Liisa. 2013. "Bakhtin's Concept of the Chronotope: The Viewpoint of an Acting Subject.” In Bakhtin and his Others: (Inter)subjectivity, Chronotope, Dialogism, edited by Liisa Steinby and Tintti Klapuri, 105-127. London and New York: Anthem Press.

Straub, Kristina. 2009. Domestic Affairs: Intimacy, Eroticism, and Violence between Servants and Masters in Eighteenth-Century Britain. Maryland: The Johns Hopkins University Press. 